\title{
Local industrial production in EAC \& Uganda (reflecting on the AfCFTA and the emergence of COVID-19): legal framework
}

\author{
by Gloria KEMBABAZI*
}

\begin{abstract}
This paper analyses the state of local industrial production in Uganda and how the emergence of COVID-19 has impacted it. This analysis bears in mind the regional context of Uganda as Partner State of the East African Community and a member of the African Union. Both of these institutions have mechanisms that impact on trade and relatedly on local industrial production, most notably the newly established African Continental Free Trade Area (AfCFTA). Overall, the paper makes a case for furthering local industrial production drawing on the lessons from the economic and developmental impact that the pandemic has wrought on the country.
\end{abstract}

\section{A. INTRODUCTION}

Local industrial production is important for a country's development. It refers to all domestic production that feeds into a country's total export capacity. It is therefore critical that a country must produce locally for the needs of its population and produce even more strategically for the external markets so as to improve its balance of trade which can be an indicator of the strength of a country's economy. Uganda as a Partner State of the East African Community and a member of the African Union which has indication on Uganda's local industrial production in aspects related to market, both for inputs and outputs, and legal frameworks. With the emergence of COVID-19 a lot of aspects related to local industrial production have been impacted given the pandemic's effects on health and the economy and the disproportionate disruption in developing countries.

\section{IMPACT OF THE PANDEMIC ON LEAST DEVELOPED COUNTRIES}

Due to the pandemic economic and financial shocks prevail and this means that for developing countries whose economies were already weak there is even more shocks to absorb that present risk of losing gains attained previously. Least developed countries (LDCs) are defined as low-income countries confronting severe structural impediments to sustainable development making them highly vulnerable to economic and environmental shocks and

* The author is a Ugandan lawyer with specialisation in regional integration. She holds an LLB (UCU), PgDLP (LDC), and LLM (UDSM) and can be reached on glorinice@yahoo.com. 
have low levels of human assets. ${ }^{1}$ Even though COVID-19 started as a health shock, it quickly evolved into an economic one as measures to restrict its spread became more and more restrictive to human mobility and economic activity consequently deepening the impact of the pandemic on low developed countries. Uganda is on the list of least developed countries that contains forty-seven countries in total. ${ }^{2}$ The World Bank estimates that Uganda's real GDP growth in 2020 is projected to hover below $2 \%$ compared with almost $5.6 \%$ in 2019 due to COVID-19.

China being one of Africa's major trading partners was the first to be hit by the virus and as it became clear that COVID-19 was a highly infectious disease measures to control its spread were put in place including closure of business and restriction of movements. This impacted production as business could not be carried on as usual. This was also to be seen in the rest of the world as the spread of the virus and measures to contain it cut supply chains and shifted demand patterns, as the virus moved beyond China, invariably slowing down global production. Highly dependent on global production, the slowdown in the global economy will has also resulted into a slowdown in economic growth in East Africa. ${ }^{3}$

Africa, and specifically Uganda receives remittances from overseas that often are more than Official development assistance. Most of the remittances are wages earned from jobs that have been scrapped by the virus in a bid to stop the spread of the pandemic. These measures included lockdowns and businesses shutting which curtailed the flow of remittances following loss of jobs due to the pandemic.

Tourism constitutes 7.7 percent of the Uganda's GDP and employs close to 700,000 people. ${ }^{4}$ Tourism is a business of travel, hospitality and person to person engagement and service delivery. It therefore goes without saying that tourism is a sector that stalled following the outbreak of COVID-19 and may not fully recover until the disease is fully under control and people are comfortable and confident to travel and tour safely.

Furthermore, Africa's trade and development partners are embroiled in their own struggles at home to contain the spread of the virus so this means that Africa is no longer at the forefront of global agendas for economic support to boost development and growth. For example, foreign direct investments support Africa's capital infrastructure projects and manufacturing but with a slowdown in foreign economies, it means a slowdown in foreign direct investments on the Continent. This is despite the fact that capital infrastructure products are necessary to drive local industrial production. Uganda Investment Authority

1 United Nations Department of Economic and Social Affairs (UNDESA), Least Developed Countries (LDCs) https://www.un.org/development/desa/dpad/least-developed-country-category.html (accessed on 10th October 2020).

2 Ibid.

3 PWC Uganda, The Impact of the Corona Virus on the Uganda Economy, https://www.pwc.com/ug/ en/press-room/impact-of-the-corona-virus-on-the-uganda-economy.html (Accessed on 6th November 2020).

4 Ibid. 
(UIA) reveals that $45 \%$ of all the planned foreign direct investments into Uganda was to come from China. ${ }^{5}$

\section{B. PLAN FOR AfCFTA IN 2020}

On $30^{\text {th }}$ May 2019, the Agreement Establishing the African Continental Free Trade Agreement (AfCFTA) entered into force following 22 countries having deposited their instruments of ratification as required by the agreement. ${ }^{6}$ On $7^{\text {th }}$ July 2019 , the operational phase of the agreement was launched. The AfCFTA is planned to be governed by five operational instruments to respectively cover: rules of origin, the online negotiating forum, the monitoring and elimination of non-tariff barriers, a digital payments system and the African Trade Observatory.

On $17^{\text {th }}$ August the Official Commissioning and Handing Over of the AfCFTA Secretariat Building took place indicating that progress is being made and all is being prepared for the actual trading under this new agreement. The operationalisation of the AfCFTA was initially planned for $1^{\text {st }}$ July 2020 and that has since been postponed to $1^{\text {st }}$ January 2020 due to the disruption caused by the pandemic.

\section{COVID-19 START ADVENT IN UGANDA}

\section{RESPONSES}

On March $22^{\text {nd }}$ the government of Uganda announced lockdown measures to contain and prevent the spread of COVID-19 in the country. These measures included social distancing guidelines, closure of schools, prohibition of public gatherings, and restrictions on movement including closure of both public and private transport except for permitted essential travel. As weeks turned into months several adjustments had to be made as it became clear under a total lockdown in a country where majority workers survive on a daily wage or sales was impossible. Some of these responses reflect the adaptability of business to the situation and indicate how local production can be stimulate and crafted to fit the needs of Uganda. Below are some of the innovations that reflect strongly on local industrial production.

One of Uganda's responses has been a turn to e-commerce. With the lockdown it became imperative that solutions for continued trade and access to goods and services is facilitated. Through partnerships with development agencies and international organisations the digital economy has been boosted. For example, the SafeBoda mobile application evolved beyond motorcycle hailing to include an e-commerce platform to connect market vendors

5 Ibid.

6 Article 23 of the Agreement Establishing the African Continental Free Trade Agreement. 
with customers. ${ }^{7}$ This enables customers to place orders through the app, pay and have riders deliver the goods. This has boosted sales and ensured access to goods.

Relatedly, has also been the changes made by Jumia Uganda in the face of the pandemic when lockdown introduced restriction on movement that impacted business flow and cut off supply chains affecting incomes and livelihoods. Jumia Food Uganda in partnership with the United Nations Development Programme (UNDP) introduced an e-commerce platform to sustain supply chains and livelihoods during the pandemic. ${ }^{8}$ The innovative e-commerce platform is set to serve vendors in Nakasero, Nakawa, Wandegeya, Bugolobi and Kalerwe, -five markets in Kampala city. At present it is estimated that 3,000 market vendors from 7 markets are now connected with $60 \%$ being women, youth and persons with disabilities. ${ }^{9}$

In the Jumia-UNDP partnership, UNDP provides smartphones, airtime and data to market vendors and supports the strengthening of an innovation ecosystem around e-commerce. ${ }^{10}$ Jumia avails its dedicated ordering platform via app and website including the last-mile distribution network and diverse set of payment methods, quality assurance and facilitation of training for the market vendors.

\section{LEGAL AND INSTITUTIONAL FRAMEWORK REGARDING LAWS ON LOCAL INDUSTRIAL PRODUCTION}

\section{EAC Level}

The EAC Trade Negotiations Framework (TNF), 2016 is the key reference for trade negotiations with third parties. Its goal is to ensure that the EAC's interests are keenly regarded and paid attention to in trade negotiations. Under the Trade Negotiations Framework, EAC's priority areas in trade negotiations include the following: the elimination of trade barriers related to customs, Sanitary and Phytosanitary and Technical Barriers to trade issues; rules of origins that promote industrialization and value addition within the EAC; and the pursuit of tariff liberalization while ensuring the protection of "sensitive" sectors, infant industries and SMEs. ${ }^{11}$

7 United Nations Conference on Trade (UNCTAD), Ugandan e-Commerce Platforms Power Recovery from COVID-19 Crisis, https://unctad.org/news/ugandan-e-commerce-platforms-power-recover y-covid-19-crisis (Accessed on 20th October 2020).

8 United Nations Development Programme (UNDP), COVID-19: UNDP, JUMIA Ugana Partner to Link Market Vendors with Consumers Online, https://www.ug.undp.org/content/uganda/en/home/ presscenter/pressreleases/2020/covid-19--undp--jumia-uganda-partner-to-link-market-vendors-wit h.html (Accessed 24th October 2020).

9 Ibid. No.7.

$10 U N C D F$, Uganda Looks Online for Answers to COVID Economic Crisis, https://news.un.org/en/st ory/2020/08/1070102 (Accessed 1st November 2020).

11 World Trade Organisation (WTO), https://www.wto.org/english/tratop_e/tpr_e/s384_e.pdf (Accessed 27th October 2020). 
The EAC also has a Committee on Communication, Trade and Investment. This Committee is responsible for the continued deliberations concerning trade and investment and is therefore critical for driving local industrial production.

EAC Priorities 2017-2021 are in line with improving local industrial production. They are seven in total namely: consolidating the Single Customs Territory, infrastructure development in the region, enhancing free movement of all factors on production across Partner States, enhancement of regional industrial development, improvement of agricultural productivity and value addition, promotion of regional peace, security and good governance; institutional transformation at the regional and Partner State levels. ${ }^{12}$

Important to note is the East African Community Competition Authority (EACA) which is mandated to promote and protect fair trade and to ensure consumer welfare in the community in line with the EAC Competition Act. ${ }^{13}$ This is especially important as an atmosphere of fairly regulated competition can incentivise production and innovation within the economy.

\section{Africa $C D C$}

Africa CDC is a specialized technical institution of the African Union established to support public health initiatives of Member States and strengthen the capacity of their public health institutions to detect, prevent, control and respond quickly and effectively to disease threats. ${ }^{14}$ The idea for an African centre for disease control and prevention emerged following the Ebola outbreak in Sierra Leone, Guinea and Liberia in 2013. ${ }^{15}$ The Africa CDC was established in January 2016 and officially launched a year later in January 2017, a timely period ahead of the pandemic that now engulfs the world. African Union through Africa CDC has provided collective action and solidarity in response to COVID-19.

One of the biggest challenges in responding to COVID-19 has been Africa's weak health systems and equipment shortages. In response Africa CDC fills the gap and is on the ground with five regional collaborative centres in Nigeria, Kenya, Zambia, Gabon and Egypt. Several African countries, through the work of Africa CDC, have set up national public health institutes.

\section{E. LESSONS ON ECONOMIC AND HUMAN COST OF DISEASE OUTBREAKS}

Disease outbreaks have always left a huge economic and social impact on African countries and the previous experiences can reveal some lessons. The Economic cost of the Ebola out-

12 East African Community (EAC), https://www.eac.int/ (Accessed 27 ${ }^{\text {th }}$ October 2020).

13 EAC Competition Act, 2006.

14 Africa Centres for Disease Control and Prevention (AfricaCDC), Our History, https://africacdc.org /about-us/our-history/ (Accessed $2^{\text {nd }}$ November 2020).

15 Carl Manlan, A CDC for Africa, https://www.scientificamerican.com/article/a-cdc-for-africa/ (Accessed on $26^{\text {th }}$ October 2020). 
break in West Africa in Sierra Leonne, Guinea and Liberia, the worst hit countries was estimated to be up to USD 4 billion dollars. ${ }^{16}$ World Health Organization statistics show that more than 400,000 people died from malaria in 2015, and 92 percent of those deaths occurred in sub-Saharan Africa. Further, six countries in Africa account for 47 percent of all global malaria cases. ${ }^{17}$

Some economically strategic events cannot be leveraged due to the current pandemic. For instance, the three-day China International Coffee Specialty Expo which has been scheduled to take place has been postponed indefinitely. China is a major market for Uganda coffee and Uganda was to be the "portrait country" at this Expo. ${ }^{18}$

Uganda and by extension Africa's largest trade partners have been most hit by the pandemic and as such planned economic cooperation has been impacted. For instance, the East African Community (EAC) and the European Union (EU) share strong trade links. The EU is the EAC's first trade partner for exports ( $25.3 \%$ of EAC exports go to the EU) and third partner for imports (12.5\% of EAC imports). ${ }^{19}$

For the future Uganda must ready itself for homegrown inputs. This involves currently planning import substitution for future shocks. The reduction in availability of imported inputs particularly due to closure of factories and businesses in China at the outset of the pandemic. ${ }^{20}$

\section{PROPOSALS FOR CHANGE}

The biggest policy and developmental move Uganda and East Africa should focus on is to improve local industrial production. Plan for the future of local production of essential goods, import substitution and increased manufacturing.

This means increased efforts to subsidise local business costs. This would encourage local entrepreneurs to venture into local industrial production. Indeed, this is one way to ensure longevity and profitability that benefits the country by protecting against profit repatriation.

Relatedly, Uganda should incentivise local production. Uganda went ahead and made local masks. This goes to show the ingenuity that is possible during a crisis. This is especially important as this pandemic has shown how much we need local alternatives when fo-

16 Ibid.

17 Ibid.

18 Ibid. No. 3.

19 European Commission, The Economic Impact of the EU-East African Community Economic Partnership Agreement, https://trade.ec.europa.eu/doclib/docs/2017/february/tradoc_155363.02\%20Ec onomic $\% 20$ Impact $\% 20$ of $\% 20$ the $\% 20$ EU\%20-\%20EAC\%20EPA.pdf (Accessed 27 $7^{\text {th }}$ October 2020).

20 Jakob Rauschendorfer and John Spray, The COVID-19 impact on Ugandan supply chains, The importance of imports, https:/www.theigc.org/wp-content/uploads/2020/08/Rauschendorfer-and-S pray-2020-policy-brief.pdf (Accessed on 26th October 2020). 
reign markets become inaccessible. For instance, $80 \%$ of inputs for manufacturing were from China or highly affected countries. ${ }^{21}$

Moreover, Uganda is a good economy for focussing on commodity-based industrialisation that is easy to scale. Take for instance the potential for commodity-based industrialisation. The cocoa-chocolate value chain is highly imbalanced and disproportionately so for African countries. Africa produces $75 \%$ of cocoa but is a net importer of chocolate. ${ }^{22}$ East Africa as a region could profitably focus on highly produced commodities to focus on for industrialisation efforts thereby profiting from the already available inputs to drive manufacturing.

The importance of data and technology is also one to be increased. With the pandemic, all decisions are now being made based on data and e-systems and platforms. An e-payments law is underway and has already been approved by parliament in Uganda and this is a step in the right direction. It is important that all forms of technology that can support development be prioritised.

Finally, health investment is imperative. If this pandemic has shown anything, this the most important lesson it has taught us. Not only does the African continent face the pandemic today as one of the greatest shocks to health but other tropical diseases chief of which being malaria and infectious diseases like tuberculosis. Health investment includes aspects like Africa CDC to be expanded, or to be supported to expand its mandate to be focussed as it currently exists as solely systems-focused. Countries must also focus on improving and expanding their healthcare service and infrastructure.

21 Oscar Olaro, The Opportunities COVID-19 Presents to Rejuvenate Uganda's Manufacturing Sector, https://www.kas.de/documents/280229/8800435/Opportunities+Covid-19+Presents+for+Ugan $\mathrm{da} \% 27 \mathrm{~s}+$ Manufucturing+Sector.pdf/d2e36dc5-9f8a-a6b7-192e-990260984f00?t=1591617625169 (Accessed $1^{\text {st }}$ Novemebr 2020).

22 UNCTAD, Economic Development in Africa Report 2019, https:/unctad.org/system/files/officialdocument/edar2019_en_ch3.pdf, Pg. 108 (Accessed on 27 $7^{\text {th }}$ October 2020). 